\title{
Genetics of autism spectrum disorder
}

\author{
Sabine M Klauck ${ }^{*} 1$ \\ ${ }^{1}$ Division of Molecular Genome Analysis, Deutsches Krebsforschungszentrum, Heidelberg, Germany
}

\begin{abstract}
Autism is a highly heritable complex neurodevelopmental disorder characterized by distinct impairments of cognitive function in the field of social interaction and speech development. Different approaches have been undertaken worldwide to identify susceptibility loci or genes for autism spectrum disorders. No clear conclusions can be made today about genetic loci involved in these disorders. The review will focus on relevant results from the last decade of research with emphasis on whole genome screens and association studies.

European Journal of Human Genetics (2006) 14, 714-720. doi:10.1038/sj.ejhg.5201610
\end{abstract}

Keywords: autism; whole-genome screens; susceptibility loci; candidate genes

\section{Introduction}

The term autism has been made public in the middle of the last century by Leo Kanner ${ }^{1}$ and Hans Asperger ${ }^{2}$ describing a very specific psychopathology recognized in children. As then, especially in the last 20 years, a much more comprehensive view of the autistic symptomatology has been established. Today a couple of neurodevelopmental disorders are defined and summarized in the Diagnostic and Statistical Manual of Mental Disorders (DSM-IV) ${ }^{3}$ and International Classification of Mental and Behavioral Disorders $\left(\right.$ ICD-10) ${ }^{4}$ under the generic name pervasive developmental disorder (PDD) or autism spectrum disorder (ASD): (1) autism or autistic disorder (OMIM 209850), (2) Asperger syndrome (AS), (3) Rett syndrome (RTT) (OMIM 312750), (4) childhood disintegrative disorder (CDD) and (5) pervasive developmental disorder-not otherwise specified (PDD-NOS) or atypical autism. The three prominent characteristic areas of malfunction of ASD are (i) impairments in social interaction, (ii) impairments in verbal and non-verbal communication and (iii) restricted repetitive and stereotyped patterns of behaviour, interests and activities. ASD symptoms are recognized typically within the first 3 years of age with a lifelong persistence.

*Correspondence: Dr SM Klauck, Division of Molecular Genome Analysis, Deutsches Krebsforschungszentrum, Im Neuenheimer Feld 580, D-69120 Heidelberg, Germany.

Tel: + 496221424 745; Fax: + 496221423 454;

E-mail: s.klauck@dkfz.de

Received 12 October 2005; revised 14 February 2006; accepted 15 February 2006
Diagnostic tools for ASD have been internationally standardized for reliable diagnoses in view of the worldwide genetic studies. In addition to the diagnostic criteria of DSM-IV $^{3}$ or ICD- $10^{4}$ this has been accomplished by the release and actual development of the Autism Diagnostic Interview-Revised (ADI-R), ${ }^{5}$ a parents or caregivers questionnaire, and the Autism Diagnostic Observation Schedule-Generic (ADOS-G), ${ }^{6}$ a direct testing tool of the patients' current behavioural pattern. The prevalence for autistic disorder representing the narrow phenotype is $0.1-0.3 \%$ and $0.3-0.6 \%$ for the broader ASDs. ${ }^{7}$ There has been some concern about increased rates of ASD over time, but due to refinement of diagnostic methodology and ascertainment strategies during the last 20 years comparison of prevalence rates reported are difficult to interpret. ${ }^{7}$ ASD is a neurodevelopmental disorder caused by mainly genetic factors, based on the observation of much higher concordance rates, considering cognitive deficits and social abnormalities for a narrow or broad definition of the phenotype, of $60-92 \%$ in monozygotic twins in contrast to $0-10 \%$ in dizygotic twins in a larger British twin study. ${ }^{8}$ The heritability from this study is estimated to be more than $90 \%$, but the influence of environmental factors for the specific affected individual towards the ASD phenotype may be still considerable. Several diagnosable medical conditions show symptomatoloy of autism spectrum disorders as well (eg fragile $\mathrm{X}$ syndrome, tuberous sclerosis complex, neurofibromatosis). These cases account only for $<10 \%$ of patients with an autistic phenotype, while for the majority of 'idiopathic' ASD the underlying genetic causes 
are unknown. It is a well-accepted hypothesis that several susceptibility genes are interacting together with a complex mode of inheritance leading to the typical phenotype(s) of the autism spectrum disorder. There may be at least three to four genes involved ${ }^{9}$ but also up to 100 genes have been discussed. ${ }^{10}$ Approximately four times more males than females ${ }^{11}$ are affected pointing towards a possible involvement of the sex chromosomes and imprinting effects in the aetiology of the disorder, but no specific genes have been conclusively implicated so far. Rett syndrome showing mostly female cases has a separate status within the group of ASD, because the genetic cause of RTT has been uncovered by the identification of mutations in the MECP 2 gene located in $\mathrm{Xq} 28^{12}$ in about $80 \%$ of cases. Recently some atypical cases of RTT showed mutations in the CDKL5 gene (reviewed in Weaving et $a l^{13}$ ). Hence, a major gene defect is disease causing in the majority of RTT patients in contrast to the as yet unidentified susceptibility genes in autistic disorder, Asperger syndrome and CDD.

There are three main approaches to locate ASD susceptibility genes: whole genome screens searching for linkage in families with affected sibling pairs, gene association studies including selective candidate gene analyses, and cytogenetic studies revealing chromosomal abnormalities in mostly rare cases to pinpoint possible genetic loci with relevance for a broader spectrum of ASD patients. This review will summarize the most relevant findings of the last years with emphasis on those studies dealing mainly with the more narrow phenotypes of autistic disorder within the group of autism spectrum disorders. Specific studies have been selected by criteria of supporting findings of independent research groups towards different candidate regions or candidate genes for ASD.

\section{Whole-genome screens and fine mapping approaches}

The main goal of conducting whole-genome screens is to define regions with putative susceptibility genes for ASD for further fine mapping by association studies and consecutive detailed candidate gene screening. The study design is based on usage of families with multiple affected members, typically affected sibling pairs but also affected relative pairs. A whole set of 300-400 polymorphic markers evenly distributed over all chromosomes is genotyped within the families. Increased allele sharing with disease status of the affected family members is expressed after statistical analysis as a maximum multipoint logarithm of the odds (lod) score (MLS) value indicative of a putative susceptibility region. Fine-mapping by family-based association testing for alleles in linkage disequilibrium (LD) with the susceptibility variant is now standard in most of the recent studies to circumvent population stratification bias. Association methods have the advantage of being more powerful than linkage methods at a certain locus by detecting genes of weaker effect. ${ }^{14}$

Since the first published whole-genome screen in $1998^{15}$ another eight genome-wide screens for autistic disorder have been conducted including families residing in Europe and/or North America. ${ }^{16-23}$ Most of the screens used independent samples, but some have been also overlapping depending on the availability of central collections to multiple investigators. Furthermore, follow-up wholegenome screens have been performed by three investigation centres after successively increasing the sample size and adding more markers in the regions of interest from the first screens. ${ }^{24-27}$ There have been suggestive linkage findings with an MLS $>1$ for 19 of the autosomal chromosomes and the X chromosome (Figure 1) suggesting the presence of genetic heterogeneity between studies. Only two studies reached a genomewide significance level above the threshold of MLS 3.6 at marker D2S2188 on 2q31.1 with MLS $4.8^{24}$ and at marker D3S3037 on $3 q 26.32 .^{22}$ Several other regions of interest have emerged in more than one study, including regions on chromosomes 1p, 5q, 7q, 15q, 16p, 17q, 19p and Xq. The other loci are either unique or may represent false positives. The variable results between studies are certainly also a matter of sample heterogeneity by inclusion of patients with a variety of classification schemes. Despite using the standardized diagnostic interviews, studies differ by incorporating sibling pairs only with the diagnosis autistic disorder or also Asperger syndrome and PDD-NOS. In addition, population differences may play a role on the background of evolutionary development of marker profiles in ethnically distinct surroundings.

Two of the most interesting regions with frequent and strong evidence of linkage between studies are located on chromosomes $2 \mathrm{q}$ and $7 \mathrm{q}$ (Table 1 ), but remain still broad with $25 \mathrm{cM}$ (centimorgan) and $60 \mathrm{cM}$, respectively. Finemapping linkage screening of the $2 \mathrm{q}$ and $7 \mathrm{q}$ regions especially under consideration of the endophenotype for

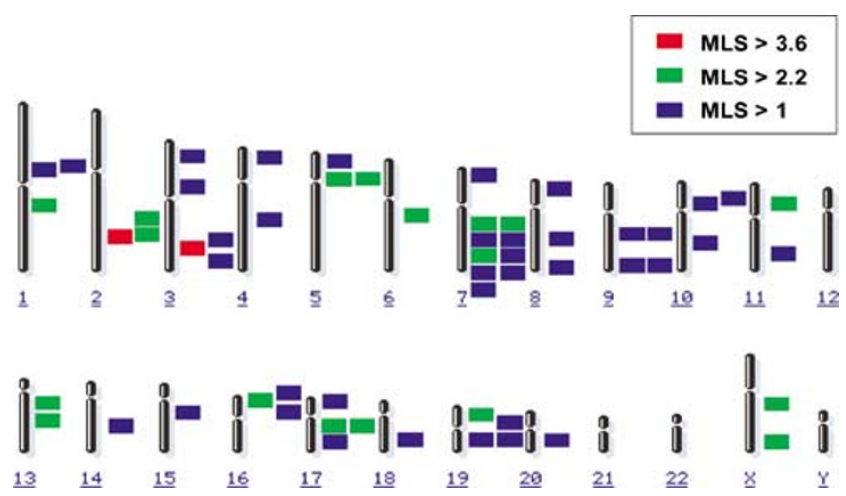

Figure 1 Whole genome screen linkage findings for autism spectrum disorders. The peak linkage findings from nine independent $^{15-23}$ and four follow-up studies ${ }^{24-27}$ are illustrated. MLS, maximum multipoint lod score. 
Table 1 Published whole-genome screen results and fine mapping linkage studies on chromosomes $2 q$ and $7 q$ with lod score $>1$ ordered according to position on chromosome

\begin{tabular}{|c|c|c|c|c|c|c|c|}
\hline $\begin{array}{l}\text { Chromosomal } \\
\text { band }\end{array}$ & Position $(C M)^{\mathrm{a}}$ & Position $(M b p)^{b}$ & $\begin{array}{l}\text { Number of } \\
\text { affected sibling } \\
\text { pairs }\end{array}$ & Results ${ }^{\mathrm{c}}$ & Research group & $\begin{array}{c}\text { Year of } \\
\text { publication }\end{array}$ & Reference \\
\hline $2 q 31.1$ & 175 & 172 & $\begin{array}{l}49 \text { 'narrow' } \\
\text { definition }\end{array}$ & HLOD 2.99 & Buxbaum & 2001 & 19 \\
\hline $\begin{array}{l}2 q 31.1 \\
2 q 31.1 \\
2 q 31.1\end{array}$ & $\begin{array}{l}176 \\
181 \\
181\end{array}$ & $\begin{array}{l}173 \\
175 \\
175\end{array}$ & $\begin{array}{l}140 \\
152 \text { total } \\
127 \text { 'strict' } \\
\text { definition }\end{array}$ & $\begin{array}{l}\text { MMHLS } 2.11 \\
\text { MMLS } 3.74 \\
\text { MMLS } 4.80\end{array}$ & $\begin{array}{l}\text { Ramoz } \\
\text { IMGSAC }^{d} \\
\text { IMGSAC }^{d}\end{array}$ & $\begin{array}{l}2004 \\
2001 \\
2001\end{array}$ & $\begin{array}{l}32 \\
24 \\
24\end{array}$ \\
\hline $\begin{array}{l}2 q 32.1 \\
2 q 33.1 \\
2 q 33.1\end{array}$ & $\begin{array}{l}183 \\
199 \\
199 \\
199\end{array}$ & $\begin{array}{l}183 \\
201 \\
201 \\
201\end{array}$ & $\begin{array}{l}95 \text { total } \\
99 \\
82 \\
45{ }^{\prime} \mathrm{PSD}^{\prime \mathrm{f}} \\
\text { definition }\end{array}$ & $\begin{array}{l}\text { HLOD } 1.96 \\
\text { MLS } 1.30 \\
\text { MMLS } 1.12 \\
\text { MLS } 2.86\end{array}$ & $\begin{array}{l}\text { Buxbaum } \\
\text { Shao }^{\mathrm{e}} \\
\text { Shao }^{\mathrm{e}} \\
\text { Shao }^{\mathrm{e}}\end{array}$ & $\begin{array}{l}2001 \\
2002 \\
2002 \\
2002\end{array}$ & $\begin{array}{l}19 \\
21 \\
31 \\
31\end{array}$ \\
\hline $7 q 21.2$ & 104 & 91 & 75 & MMLS/het 2.20 & CLSA & 1999 & 18 \\
\hline $7 q 21.2$ & 104 & 91 & $\begin{array}{l}75 \text { language } \\
\text { phenotype }\end{array}$ & MMLS/het 2.10 & Bradford $^{9}$ & 2001 & 30 \\
\hline $7 q 22.1$ & $\begin{array}{l}112 \\
112\end{array}$ & $\begin{array}{l}100 \\
100\end{array}$ & $\begin{array}{l}152 \\
153\end{array}$ & $\begin{array}{l}\text { MMLS } 3.20 \\
\text { MMLS } 3.37\end{array}$ & $\begin{array}{l}\text { IMGSAC }^{d} \\
\text { IMGSAC }^{d}\end{array}$ & $\begin{array}{l}2001 \\
2001\end{array}$ & $\begin{array}{l}24 \\
29\end{array}$ \\
\hline $7 q 31.1$ & 123 & 111 & 110 & MMHLS 1.02 & Liu & 2001 & 20 \\
\hline $7 q 31.33$ & 129 & 124 & 76 & MMLS 1.77 & Ashley-Koch & 1999 & 28 \\
\hline $7 q 32.1$ & 135 & 135 & 87 & MLS 2.53 & IMGSAC & 1998 & 15 \\
\hline $7 q 34$ & 145 & 138 & 99 & MLS 1.66 & Shao $^{h}$ & 2002 & 21 \\
\hline $7 q 35$ & 156 & 143 & $\begin{array}{l}123 \text { 'WORD' } \\
\text { definition }\end{array}$ & NPL-Z 2.98 & Alarcon ${ }^{j}$ & 2002 & 25 \\
\hline $7 q 35$ & 156 & 143 & $\begin{array}{l}298 \text { 'WORD' } \\
\text { definition' }\end{array}$ & NPL-Z 2.05 & Alarconk & 2005 & 27 \\
\hline $7 q 36.1$ & 165 & 151 & 160 & MMHLS 2.13 & Liu & 2001 & 20 \\
\hline
\end{tabular}

aposition of markers in Marshfield map taken from http://www.ncbi.nlm.nih.gov/entrez/.

${ }^{b}$ Position of markers on chromosomes taken from UCSC Human (Homo sapiens) Genome Browser Gateway (http://genome.ucsc.edu/cgi-bin/ hgGateway) using the May 2004 release of the human genome sequence.

'HLOD: heterogeneity lod score; MLS: maximum lod score; MMHLS: multipoint maximum heterogeneity lod score; MMLS: multipoint maximum lod score; MMLS/het: maximum multipoint heterogeneity lod score; NPL-Z: non-parametric lod score- $Z$.

${ }^{\mathrm{d}}$ Follow-up study of IMGSAC ${ }^{15}$ with increased sample-size.

eIndependent data sets.

fPSD: phrase speech delay.

gSame sample as CLSA. ${ }^{18}$

hollow-up study of Ashley-Koch et al. ${ }^{28}$

'WORD: ADI-R item A12, age at first word.

'Same sample as Liu et al. ${ }^{20}$

${ }^{\mathrm{k}}$ Follow-up study of Alarcon et $a l^{25}$ with increased sample-size.

delayed onset of speech resulted in further support through suggestive linkage findings in several studies. ${ }^{27,28-31}$ Attempts to locate specific candidate genes within these chromosomal regions resulted in positive association findings of the mitochondrial aspartate/glutamate carrier $S L C 25 A 12^{32}$ and CMYA3 genes, ${ }^{33}$ respectively, in $2 \mathrm{q} 24-$ q33, but negative findings are reported from an independent autism family sample. ${ }^{34}$ Ambiguous results are also known from analyses of the reelin (RELN) gene in the chromosome 7q22 linkage region and being a factor influencing neuronal migration in brain development. Positive association for a $5^{\prime}$ UTR triplet repeat polymorphism $^{35,36}$ and different SNPs ${ }^{37,38}$ could not be replicated otherwise. ${ }^{39-42}$ The low frequency of four different missense changes identified in a sample of 315 ASD families ${ }^{40}$ cannot account for the relatively strong linkage findings in 7q. Postmortem brain studies still suggest a role of the Reelin protein in the brain causing structural and cognitive deficits in autistic disorder. ${ }^{43}$ Interestingly, the gene engrailed 2 (EN2) in 7q36 with impact on cerebellar development showed positive association of intronic single nucleotide polymorphisms (SNPs) in two independent family data sets. ${ }^{44}$ Additional proof of relevance for the ASD phenotype remains to be shown for all of these candidate genes in independent autism samples.

Sex and parent of origin linkage modelling suggested possible sex-limited effects of the susceptibility loci on $7 q$, $15 q$ and $16 p$, but no such effect for loci on chromosomes 2 and $9 .{ }^{45}$ In the same study parent-of-origin effects could be shown by maternal IBD sharing on chromsome $7 q$ and $9 p$ and paternal IBD sharing on 7q. A different study identified a male-specific linkage peak of MLS 4.3 at $17 q 11 .{ }^{46}$ The gender-specific analyses and results raise the possibility of sex-specific genetic factors potentially influ- 
enced by hormone levels at the sex-limited loci and a role of imprinted gene(s) at the parent-of-origin loci, a finding which needs further evaluation in extended family samples.

Using trait subsets of the autism patient samples with specific phenotype characteristics attempt to decrease sample heterogeneity. Several linkage findings by means of endophenotypes are currently known: (1) Families with obsessive-compulsive behaviour showed suggestive linkage in $1 \mathrm{q} 24.2,{ }^{47}$ and support for previously identified linkage loci on $6 \mathrm{q} 14.3^{16}$ and $19 \mathrm{p} 13 .{ }^{15,16,20}$ (2) The factor 'developmental milestones' lead to evidence for the susceptibility loci $17 \mathrm{q} 11.2$ and $19 \mathrm{p} 13^{48}$ replicating in part other 17q11 regional findings. ${ }^{46}$ (3) A sample of 34 affected sib pairs with a history of developmental regression was analysed and the regions $21 \mathrm{q} 21.1$ and $7 q 36.1^{49}$ have been found, the latter supporting a previous linkage finding at $165 \mathrm{cM}$ on $7 \mathrm{q}$ from one of the whole genome-screens ${ }^{20}$ (Table 1). (4) Application of the statistical method of ordered-subset analysis (OSA) using the factor 'insistence of sameness' from the repetitive-stereotyped patterns domain of the ADI-R as covariate ${ }^{50}$ identified positive linkage in the $15 q 11-q 13$ region, a chromosomal region known to be the most common site of chromosomal abnormalities in this disorder. $^{51}$ (5) Screening for savant skills only lead to contradictory positive and negative linkage findings for 15q11-q13, respectively. ${ }^{52,53}$ Altogether, besides the promising outcome of the approaches by integrating categorical phenotypic measures all studies are lacking larger numbers of cases and the validity of the results remain to be elucidated in further replication studies.

Recently, a genomewide scan using 17 Finnish families with a strict diagnosis of Asperger syndrome observed positive linkage findings in a two-stage approach on chromosomal regions 1q21-q22, 3p14-24 and 13q31q33. ${ }^{54}$ The first two loci are replicative findings of previously published autism susceptibility regions. The loci on $1 \mathrm{q}$ and $13 \mathrm{q}$ overlap with reported schizophrenia susceptibility loci. These results underline the possibility that certain broader genome regions contain susceptibility genes for several distinct neuropsychiatric disorders, some of them may be shared justifying additional analyses.

\section{Chromosomal abnormalities in autism spectrum disorder}

Chromosomal abnormalities detected by cytogenetic assays are of major aid to locate relevant genes for any monogenic or polygenic disease. A number of such visible breakpoints, translocations, duplications and deletions have been reported for predominantly individual cases of ASD spreading over all chromosomes as was extensively reviewed recently. ${ }^{51,55}$ At this point no direct correlation could be made towards a genomic region inheriting a susceptibility gene for autism. However, integration of data from linkage analyses and reports of chromosomal abnormalities are useful to narrow down genomic regions of interest for fine mapping of susceptibility genes.

The chromosomal region $15 \mathrm{q} 11-\mathrm{q} 13$ has gained much attention due to frequent reports of duplications of mainly maternal origin. ${ }^{51}$ The region of interest hosts a cluster of $\gamma$-amino butyric acid $\left(\mathrm{GABA}_{\mathrm{A}}\right)$ receptor subunit genes (GABRB3, GABRA5 and GABRG3). Any malfunction of these genes may have implications for the inhibition of excitatory neural pathways as well as during early brain development and therefore pathological for autism. A couple of linkage and association studies reported limited evidence for involvement of the $\mathrm{GABA}_{\mathrm{A}}$ receptors, where the most common positive linkage finding was within the GABRB3 gene. $^{56-60}$

One other region of interest has been the subtelomeric region of $2 q 37$ with a higher frequency of deletions in comparison to other chromosomal areas. ${ }^{61-63}$ Detailed analysis of a larger patient sample for variants in the CENTG2 gene revealed a limited number of autism specific non-synonymous variants but no evidence for linkage disequilibrium. ${ }^{64}$ Therefore, the involvement of other genes in the 2q37 region should be considered. Technology developments such as matrix-based comparative genomic hybridisation $(\mathrm{m}-\mathrm{CGH})^{65}$ and representational oligonucleotide microarray analysis ${ }^{66}$ will allow to pinpoint autism-related genomic loci by screening of larger patient samples for much smaller duplication or deletion regions in the future. It remains to disentangle whether identified genomic imbalances are truly involved with the disease or represent large-scale copy number polymorphisms in the human genome. ${ }^{67,68}$

\section{Candidate gene screening}

Different criteria make a gene or genetic locus eligible for association studies or further screening for variants or mutations. The gene or gene product (i) is thought to be of relevance for behaviour in humans, (ii) belongs to a neurodevelopmental pathway in the brain by expression in foetal brain tissues, (iii) has been implicated through studies of animal models, (iv) has been identified through a chromosomal abnormality, and (v) has been located positionally by linkage studies.

Over the last decade manifold candidate studies have been conducted following up on potential susceptibility loci in ASD. The majority of them did not reveal a clear picture of either positive association at a certain gene or genomic locus or identification of disease-relevant variations or mutations by comparison of individual studies. This might be the result of allelic heterogeneity, sample heterogeneity, small samples sizes or ethnically distinct backgrounds. More than 100 functional or positional candidate genes have been tested directly but lacking conclusive evidence of involvement in ASD. It is impos- 
sible to review all studies here, however, examples of two genes should demonstrate the worldwide efforts and remaining difficulty to discover their role in ASD.

Genes involved in the physiological pathway of serotonin are strong candidates for autism as serotonin serves as a neurotransmitter in the brain responsible for a couple of cognitive functions. Hyperserotonemia has been reported in autism leaving the serotonin transporter (SLC6A4 or 5-HTT) gene responsible for serotonin reuptake at the presynaptic membrane of neurons as primary target of extensive investigations. The results of the numerous studies are inconsistent reporting either association of different alleles of the functional promoter polymorphism 5-HTTLPR (short or long allele) involved in gene expression or no evidence for association (reviewed in Devlin et al $^{69}$ ). The finding that the recently identified single nucleotide polymorphism (SNP) rs25531 with its A variant in the long allele of 5-HTTLPR sequence is responsible for the high 5-HTT mRNA level may explain the ambiguous results of previous association studies with the need of more detailed genotyping in the future. ${ }^{70}$ Other SNPs in 5-HTT show strong transmission disequilibrium with autism. ${ }^{71}$ Positive linkage findings from genome screens at the 17q11.2-q12 locus $^{24,26,48}$ spot this gene locus as well. Extensive variant screening identified several rare coding (eg Gly56Ala) and non-coding variants in 5-HTT with a strong correlation to the endophenotype of rigid-compulsive behaviour. ${ }^{72}$ Together with the report of another rare functional coding variant Ile425Leu in a sample of patients with complex neuropsychiatric phenotypes (obsessive-compulsive disorder, Asperger syndrome, social phobia, anorexia nervosa, tic disorder, alcohol and other substance abuse/dependence $)^{73}$ this demonstrates that allelic heterogeneity of 5-HTT potentially supports disease risk for related phenotypes including autism.

Hints from linkage studies ${ }^{21,22}$ and reports from chromosomal deletions in three autistic females ${ }^{74}$ lead to the screening of the genes neuroligin 3 (NLGN3) at Xp22.3 and 4 (NLGN4) at Xq13. The neuroligins are cell-adhesion proteins with important function in synaptogenesis during brain development and in connection of pre- and postsynaptic membranes. A frameshift mutation in NLGN4 and a missense mutation in NLGN3 in two separate families have been found ${ }^{75}$ leading to functional inactivation of neuroligins. ${ }^{76}$ Another 2-base-pair deletion within NLGN4 was found in a large family segregating with X-linked mental retardation including three males with ASD. ${ }^{77}$ Mutations in these neuroligin genes seem to be rather rare events. Extensive screening of other large patient samples only revealed four other missense mutations with questionable function in $N L G N 4{ }^{78}$ but otherwise negative results have been reported. ${ }^{79-82}$ It remains to be shown whether other genes with function in synaptogenesis and which act together with the neuroligins are involved in ASD.

\section{Future directions}

Through the last decade a lot of information has been gained towards the identification of susceptibility genes for autism spectrum disorders. The diagnostic criteria for ASD have been refined to facilitate detailed analyses including endophenotypes together with knowledge from systematic molecular genetic screening approaches, such as whole genome screens, association studies and candidate gene screenings. Despite much progress the final definition of susceptibility genes underlying ASD is still a challenge for the future. The ultimate goal is to define a series of genetic variants to be responsible for a specific symptomatology within the whole spectrum of disabilities in ASD. To accomplish this, technologies such as whole genome association studies making use of high throughput genotyping methods are promising to support the identification of disease genes for complex disorders keeping in mind problems with multiple testing, study design, definition of intermediate phenotypes and interaction between polymorphisms. ${ }^{83}$ The International HapMap Project determines the common patterns of DNA sequence variants in the human genome, the degree of association between them in terms of strong linkage disequilibrium, known as haplotype blocks, and gains insights into structural variation and recombination. ${ }^{84}$ This information is needed to integrate disease relevant variants with knowledge of common population variants for the autism projects as well.

Since 2003 a large-scale, collaborative genetics research project, the Autism Genome Project (AGP), initiated by the National Alliance for Autism Research (NAAR) and the National Institute of Health, has been started to focus on the genetics of autism and includes the world leading autism consortia (http://www.naar.org/news/pdfs/agp1a. pdf, $\left.{ }^{85}\right)$. The project includes more than 1500 multiplex families, which are used within a whole-genome screen utilizing both SNP array and microsatellite technology. Regions of interest from this meta-analyis will be further fine-mapped and sequenced to evaluate the exact nucleotides giving rise to predisposition for ASD. Alternative much more emphasis should be put into gene function and pathway analyses to understand the development of brain structures and their function in cognitive processing. From this knowledge it may be possible to develop therapeutic targets for drug treatments but much important also screening diagnostics that would allow for early intervention with behavioural therapies of individuals inheriting risk factors for autism spectrum disorders.

\section{Acknowledgements}

I thank Annemarie Poustka for continuous support for autism research and fruitful discussions who has made this manuscript possible. 


\section{References}

1 Kanner L: Autistic disturbances of affective contact. Nerv Child 1943; 2: 217-250.

2 Asperger H: Die autistischen psychopathen im kindesalter. Arch Psychiatr Nervenkr 1944; 117: 76-136.

3 American Psychiatric Association: Diagnostic and statistical manual of mental disorders, 4th edn. Washington, DC, USA: American Psychiatric Association, 1994.

4 World Health Organization: International classification of mental and behavioral disorders. Clinical descriptions and diagnostic guidelines, 10th edn. Geneva: World Health Organization, 1992.

5 Lord C, Rutter M, Le Couteur A: Autism diagnostic interviewrevised: a revised version of a diagnostic interview for caregivers of individuals with possible pervasive developmental disorders. J Autism Dev Disord 1994; 24: 659-685.

6 Lord C, Risi S, Lambrecht L et al: The autism diagnostic observation schedule-generic: a standard measure of social and communication deficits associated with the spectrum of autism. J Autism Dev Disord 2000; 30: 205-223.

7 Fombonne E: Epidemiological surveys of autism and other pervasive developmental disorders: an update. J Autism Dev Disord 2003; 33: 365-382.

8 Bailey A, Le Couteur A, Gottesman I et al: Autism as a strongly genetic disorder: evidence from a British twin study. Psychol Med 1995; 25: 63-78.

9 Pickles A, Bolton P, Macdonald $\mathrm{H}$ et al: Latent-class analysis of recurrence risks for complex phenotypes with selection and measurement error: a twin and family history study of autism. Am J Hum Genet 1995; 57: 717-726.

10 Pritchard JK: Are rare variants responsible for susceptibility to complex diseases? Am J Hum Genet 2001; 69: 124-137.

11 Smalley SL: Genetic influences in childhood-onset psychiatric disorders: autism and attention-deficit/hyperactivity disorder. Am J Hum Genet 1997; 60: 1276-1282.

12 Amir RE, Van den Veyver IB, Wan M, Tran CQ, Francke U, Zoghbi HY: Rett syndrome is caused by mutations in X-linked MECP2, encoding methyl-CpG-binding protein 2. Nat Genet 1999; 23: $185-188$.

13 Weaving LS, Ellaway CJ, Gécz J, Christodoulou J: Rett syndrome: clinical review and genetic update. $J$ Med Genet 2005; 42: $1-7$.

14 Risch N, Merikangas K: The future of genetic studies of complex human disease. Science 1996; 273: 1516-1517.

15 International Molecular Genetic Study of Autism Consortium: A full genome screen for autism with evidence for linkage to a region on chromosome 7q. Hum Mol Genet 1998; 7: 571-578.

16 Philippe A, Martinez M, Guilloud-Bataille $M$ et al: Genome-wide scan for autism susceptibility genes. Paris Autism Research International Sibpair Study. Hum Mol Genet 1999; 8: 805-812.

17 Risch N, Spiker D, Lotspeich L et al: A genomic screen of autism: evidence for a multilocus etiology. Am J Hum Genet 1999; 65: $493-507$.

18 Barrett S, Beck JC, Bernier R et al: An autosomal genomic screen for autism. Collaborative Linkage Study of Autism. Am J Med Genet 1999; 88: 609-615.

19 Buxbaum JD, Silverman JM, Smith CJ et al: Evidence for a susceptibility gene for autism on chromosome 2 and for genetic heterogeneity. Am J Hum Genet 2001; 68: 1514-1520.

20 Liu J, Nyholt DR, Magnussen P et al: A genomewide screen for autism susceptibility loci. Am J Hum Genet 2001; 69: 327-340.

21 Shao Y, Wolpert CM, Raiford KL et al: Genomic screen and followup analysis for autistic disorder. Am J Med Genet (Neuropsychiatr Genet) 2002; 114: 99-105

22 Auranen M, Vanhala R, Varilo $\mathrm{T}$ et al: A genomewide screen for autism-spectrum disorders: evidence for a major susceptibility locus on chromosome 3q25-27. Am J Hum Genet 2002; 71: 777-790.

23 Cantor RM, Kono N, Duvall JA et al: Replication of autism linkage: fine-mapping peak at 17q21. Am J Hum Genet 2005; 76: $1050-1056$
24 International Molecular Genetic Study of Autism Consortium (IMGSAC): A genomewide screen for autism: strong evidence for linkage to chromosomes 2q, 7q, and 16p. Am J Hum Genet 2001; 69: $570-581$.

25 Alarcón M, Cantor RM, Liu J et al: Evidence for a language quantitative trait locus on chromosome $7 \mathrm{q}$ in multiplex autism families. Am J Hum Genet 2002; 70: 60-71.

26 Yonan AL, Alarcon M, Cheng R et al: A genomewide screen of 345 families for autism-susceptibility loci. Am J Hum Genet 2003; 73: 886-897.

27 Alarcón M, Yonan AL, Gilliam TC, Cantor RM, Geschwind DH: Quantitative genome scan and ordered-subsets analysis of autism endophenotypes support language QTLs. Mol Psychiatry 2005; 10: $747-757$.

28 Ashley-Koch A, Wolpert CM, Menold MM et al: Genetic studies of autistic disorder and chromosome 7. Genomics 1999; 61: $227-236$.

29 International Molecular Genetic Study of Autism Consortium (IMGSAC): Further characterization of the autism susceptibility locus AUTS1 on chromosome 7q. Hum Mol Genet 2001; 10: 973-982.

30 Bradford $\mathrm{Y}$, Haines $\mathrm{J}$, Hutcheson $\mathrm{H}$ et al: Incorporating language phenotypes strengthens evidence of linkage to autism. Am J Med Genet (Neuropsychiatr Genet) 2001; 105: 539-547.

31 Shao Y, Raiford KL, Wolpert CM et al: Phenotypic homogeneity provides increased support for linkage on chromosome 2 in autistic disorder. Am J Hum Genet 2002; 70: 1058-1061.

32 Ramoz N, Reichert JG, Smith CJ et al: Linkage and association of the mitochondrial aspartate/glutamate carrier SLC25A12 gene with autism. Am J Psychiatry 2004; 161: 662-669.

33 Faham M, Zheng J, Moorhead M et al: Multiplexed variation scanning for 1000 amplicons in hundreds of patients using mismatch repair detection (MRD) on tag arrays. Proc Natl Acad Sci USA 2005; 102: 14717-14722.

34 Blasi F, Bacchelli E, Carone S et al: SLC25A12 and CMYA3 gene variants are not associated with autism in the IMGSAC multiplex sample. Eur J Hum Genet 2006; 14: 123-126.

35 Persico AM, D'Agruma L, Maiorano N et al: Reelin gene alleles and haplotypes as a factor predisposing to autistic disorder. Mol Psychiatry 2001; 6: 150-159.

36 Zhang $\mathrm{H}$, Liu X, Zhang $\mathrm{C}$ et al: Reelin gene alleles and susceptibility to autism spectrum disorders. Mol Psychiatry 2002; 7: $1012-1017$.

37 Skaar DA, Shao Y, Haines JL et al: Analysis of the RELN gene as genetic risk factor for autism. Mol Psychiatry 2005; 10: $563-571$.

38 Serajee FJ, Zhong H, Mahbubul Huq AHM: Association of reelin gene polymorphisms with autism. Genomics 2006; 87: $75-83$.

39 Krebs MO, Betancur C, Leroy S et al: Absence of association between a polymorphic GGC repeat in the $5^{\prime}$ untranslated region of the reelin gene and autism. Mol Psychiatry 2002; 7: 801-804.

40 Bonora E, Beyer KS, Lamb JA et al: Analysis of reelin as a candidate gene for autism. Mol Psychiatry 2003; 8: 885-892.

41 Devlin B, Bennett P, Dawson G et al: Alleles of a reelin CGG repeat do not convey liability to autism in a sample from the CPEA network. Am J Med Genet Part B (Neuropsychiatr Genet) 2004; 126B: $46-50$.

42 Li J, Nguyen L, Gleason C et al: Lack of evidence for an association between WNT2 and RELN polymorphisms and autism. Am J Med Genet Part B (Neuropsychiatr Genet) 2004; 126B: 51-57.

43 Fatemi SH, Snow AV, Stary JM et al: Reelin signalling is impaired in autism. Biol Psychiatry 2005; 57: 777-787.

44 Benayed R, Gharani N, Rossman I et al: Support for the homeobox transcription factor gene ENGRAILED 2 as an autism spectrum disorder susceptibility locus. Am J Hum Genet 2005; 77: 851-868.

45 Lamb JA, Barnby G, Bonora E et al: Analysis of IMGSAC autism susceptibility loci: evidence for sex limited and parent of origin specific effects. J Med Genet 2005; 42: 132-137. 
46 Stone JL, Merriman B, Cantor R et al: Evidence for sex-specific risk alleles in autism spectrum disorder. Am J Hum Genet 2004; 75: $1117-1123$.

47 Buxbaum JD, Silverman J, Keddache $\mathrm{M}$ et al: Linkage analysis for autism in a subset of families with obsessive-compulsive behaviors: Evidence for an autism susceptibility gene on chromosome 1 and further support for susceptibility genes on chromosome 6 and 19. Mol Psychiatry 2004; 9: 144-150.

48 McCauley JL, Li C, Jiang L et al: Genome-wide and ordered-subset linkage analyses provide support for autism loci on $17 \mathrm{q}$ and $19 \mathrm{p}$ with evidence of phenotypic and interlocus genetic correlates. BMC Med Genet 2005; 6: 1.

49 Molloy CA, Keddache M, Martin LJ: Evidence for linkage on 21q and $7 \mathrm{q}$ in a subset of autism characterized by developmental regression. Mol Psychiatry 2005; 10: 741-746.

50 Shao Y, Cuccaro ML, Hauser ER et al: Fine mapping of autistic disorder to chromosome $15 \mathrm{q} 11-\mathrm{q} 13$ by use of phenotypic subtypes. Am J Hum Genet 2003; 72: 539-548.

51 Vorstman JA, Staal WG, van Daalen E et al: Identification of novel autism candidate regions through analysis of reported cytogenetic abnormalities associated with autism. Mol Psychiatry 2006; 11: $18-28$.

52 Nurmi EL, Dowd M, Tadevosyan-Leyfer O, Haines JL, Folstein SE, Sutcliffe JS: Exploratory subsetting of autism families based on savant skills improves evidence of genetic linkage to 15q11-q13. J Am Acad Child Adolesc Psychiatry 2003; 42: $856-863$

53 Ma DQ, Jaworski J, Menold MM et al: Ordered-subset analysis of savant skills in autism for $15 \mathrm{q} 11-\mathrm{q} 13$. Am J Med Genet Part B (Neuropsychiatr Genet) 2005; 135B: 38-41.

54 Ylisaukko-oja T, Nieminen-von Wendt T, Kempas E et al: Genome-wide scan for loci of Asperger syndrome. Mol Psychiatry 2004; 9: $161-168$

55 Castermans D, Wilquet V, Steyaert J, Van de Ven W, Fryns J-P, Devriendt K: Chromosomal anomalies in individuals with autism. Autism 2004; 8: 141-161.

56 Cook Jr EH, Courchesne RY, Cox NJ et al: Linkage-disequilibrium mapping of autistic disorder, with 15q11-13 markers. Am J Hum Genet 1998; 62: 1077-1083.

57 Martin ER, Menold MM, Wolpert CM et al: Analysis of linkage disequilibrium in $\gamma$-aminobutyric acid receptor subunit genes in autistic disorder. Am J Med Genet (Neuropsychiatr Genet) 2000; 96: $43-48$.

58 Buxbaum JD, Silverman JM, Smith CJ et al: Association between a GABRB3 polymorphism and autism. Mol Psychiatry 2002; 7: $311-316$.

59 McCauley JL, Olson LM, Delahanty R et al: A linkage disequilibrium map of the $1-\mathrm{Mb} 15 \mathrm{q} 12 \mathrm{GABA}_{\mathrm{A}}$ receptor subunit cluster and association to autism. Am J Med Genet Part B (Neuropsychiatr Genet) 2004; 131B: 51-59.

60 Curran S, Roberts S, Thomas S et al: An association analysis of microsatellite markers across the Prader-Willi/Angelman critical region on chromsome 15 (q11-13) and autism spectrum disorder. Am J Med Genet B Neuropsychiatr Genet 2005; 137B: $25-28$.

61 Ghaziuddin M, Burmeister M: Deletion of chromosome 2 q37 and autism: a distinct subtype? J Autism Dev Disord 1999; 29: $259-263$.

62 Wolff DJ, Clifton K, Karr C, Charles J: Pilot assessment of the subtelomeric regions of children with autism: detection of a $2 \mathrm{q}$ deletion. Genet Med 2002; 4: 10-14.

63 Lukusa T, Vermeesch JR, Holvoet M, Fryns JP, Devriendt K: Deletion 2q37.3 and autism: molecular cytogenetic mapping of the candidate region for autistic disorder. Genet Counsel 2004; 15: $293-301$

64 Wassink TH, Piven J, Vieland VJ et al: Evaluation of the chromosome 2q37.3 gene CENTG2 as an autism susceptibility gene. Am J Med Genet Part B (Neuropsychiatr Genet) 2005; 136B: $36-44$.
65 Solinas-Toldo S, Lampel S, Stilgenbauer S et al: Matrix-based comparative genomic hybridisation: biochips to screen for genomic imbalances. Genes Chromosomes Cancer 1997; 20: 399-407.

66 Lucito R, Healy J, Alexander J et al: Representational oligo nucleotide microarray analysis: a high-resolution method to detect genome copy number variation. Genome Res 2003; 13: $2291-2305$

67 Sebat J, Lakshmi B, Troge J et al: Large-scale copy number polymorphism in the human genome. Science 2004; 305: $525-528$.

68 Iafrate AJ, Feuk L, Rivera M et al: Detection of large-scale variation in the human genome. Nat Genet 2004; 36: 949-951.

69 Devlin B, Cook Jr EH, Coon $\mathrm{H}$ et al: Autism and the serotonin transporter: the long and short of it. Mol Psychiatry 2005; 10: $1110-1116$.

70 Wendland JR, Martin BJ, Kruse MR, Lesch K-P, Murphy DL: Simultaneous genotyping of four functional loci of human SLC6A4, with reappraisal of 5-HTTLPR and rs25531. Mol Psychiatry 2006; 11: 224-226.

71 Kim SJ, Cox N, Courchesne R et al: Transmission disequilibrium mapping at the serotonin transporter gene (SLC6A4) region in autistic disorder. Mol Psychiatry 2002; 7: 278-288.

72 Sutcliffe JS, Delahanty RJ, Prasad HC et al: Allelic heterogeneity at the serotonin transporter locus (SLC6A4) confers susceptibility to autism and rigid-compulsive behaviors. Am J Hum Genet 2005; 77: $265-279$.

73 Ozaki N, Goldman d, Kaye WH et al: Serotonin transporter missense mutation associated with a complex neuropsychiatric phenotype. Mol Psychiatry 2003; 8: 933-936.

74 Thomas NS, Sharp AJ, Browne CE, Skuse D, Hardie C, Dennis NR: $\mathrm{Xp}$ deletions associated with autism in three females. Hum Genet 1999; 104: 43-48.

75 Jamain S, Quach H, Betancour C et al: Mutations of the X-linked genes encoding neuroligins NLGN3 and NLGN4 are associated with autism. Nat Genet 2003; 34: 27-29.

76 Chih B, Afridi SK, Clark L, Scheiffele P: Disorder-associated mutations lead to functional inactivation of neuroligins. Hum Mol Genet 2004; 13: 1471-1477.

77 Laumonnier F, Bonnet-Brilhault F, Gomot M et al: X-linked mental retardation and autism are associated with a mutation in the NLGN4 gene, a member of the neuroligin family. Am J Hum Genet 2004; 74: 552-557.

78 Yan J, Oliveira G, Coutinho A et al: Analysis of the neuroligin 3 and 4 genes in autism and other neuropsychiatric patients. Mol Psychiatry 2005; 10: 329-335.

79 Vincent JB, Kolozsvari D, Roberts WS, Bolton PF, Gurling HMD, Scherer SW: Mutation screening of X-chromosomal neuroligin genes: no mutations in 196 autism probands. Am J Med Genet Part $B$ (Neuropsychiatr Genet) 2004; 129B: 82-84.

80 Talebizadeh Z, Bittel DC, Veatch O, Butler M, Takahashi TN, Miles JH: Do known mutations in neuroligin genes (NLGN3 and NLGN4) cause autism? J Autism Dev Disord 2004; 34: $735-736$.

81 Gauthier J, Bonnel A, St-Onge J et al: NLGN3/NLGN4 gene mutations are not responsible for autism in the Quebec population. Am J Med Genet Part B (Neuropsychiatr Genet) 2005; 132B: 74-75.

82 Ylisaukko-oja T, Rehnström K, Auranen M et al: Analysis of four neuroligin genes as candidates for autism. Eur J Hum Genet 2005; 13: $1285-1292$.

83 Carlson CS, Eberle MA, Kruglyak L, Nickerson DA: Mapping complex disease loci in whole-genome association studies. Nature 2004; 429: 446-452.

84 The International HapMap Consortium: A haplotype map of the human genome. Nature 2005; 437: 1299-1320.

85 Hu-Lince D, Craig DW, Huentelman MJ, Stephan DA: The autism genome project: goals and strategies. Am I Pharmacogenomics 2005; 5: 233-246. 